\title{
THE PRICING STRATEGIES OF HUNGARIAN FOOD RETAIL CHAINS DURING THE LAST RECESSION*
}

\author{
Zombor BEREZVAI \\ (Received: 24 October 2013; revision received: 6 February 2014; \\ accepted:13 February 2014)
}

\begin{abstract}
The paper seeks to explore the pricing strategies used by Hungarian food retail chains and how these strategies are related to the market and financial performance of the chains. A two-phase empirical research was carried out in 2011/2012. The research is based on 44 in-store observations, the analysis of price promotion leaflets and interviews with retail professionals. In-store observations focused on collecting data on baseline prices. The price promotion leaflets enabled the assessment of the promotional activity of the observed retailers. The interviews were used to check the validity of the research results. By grouping the analysed 11 retail chains along baseline price levels and price promotion activities, three different types of pricing strategies were identified. A relationship was found between the three pricing strategies and the performance indicators of the included chains. An important finding is that retail chains with a medium price level and low promotional activity were the least successful, while retailers with a low price level and high promotional activity achieved the best performance.
\end{abstract}

Keywords: retailing, pricing strategy, promotion, economic crisis, Hungary

JEL classification indices: M31, M37

* The author would like to thank Irma Agárdi and Julianna Gálik for their encouragement and support. The author would also like to thank Márton Szabó, Gabriella Mile, Márta Stauder, Márton Edelényi, Attila Fodor and Aliz McLean for their comments on previous versions of the article.

Zombor Berezvai, MA student, Department of Economics, Eötvös Loránd University, Budapest, Hungary. E-mail: bzombor@caesar.elte.hu 


\section{INTRODUCTION}

The purpose of this paper is to analyse the pricing strategies and their effects on the market and financial performance of retail chains in a time of recession in Hungary. This is a relevant research area considering that consumer habits changed rapidly during the economic downturn. As stated succinctly by the market research institute GfK Hungary (2011: 1), "[t]he economic crisis has served as a catalyst for the development of new consumer trends in Hungary. As a result of the fact that customers have become more price-sensitive and conscious, it can be seen that shopping occasions have also become more planned. The role of gathering information before shopping has increased, which can also be seen in the fact that more and more people read through the leaflets of the retail chains. This trend is equally true of the social strata with higher income."

The volume of retail sales of food, beverages and tobacco has significantly declined. In 2012, sales volumes were close to those of 2004. However, since 2004, two new retail chains have entered the Hungarian market (Lidl and Aldi) and others have also opened new stores. Competition has become stronger.

Changing consumer habits inevitably causes changes in retail chains' marketing policies. The most important element of these marketing policies is the pricing strategy. Pricing and promotional activity are key elements in (at least) maintaining the turnover and profitability of a chain/store. The paper identifies the currently applied pricing strategies and evaluates their effects on market and financial performance indicators.

The structure of this paper is as follows. Section 2 reviews prior studies on retail pricing. Section 3 offers a short introduction to the Hungarian food retail sector. Section 4 describes the methodology and the dataset. Section 5 presents the results and discussion. Concluding comments are presented in Section 6.

\section{LITERATURE REVIEW}

Various tools of marketing (e.g. pricing policy, TV advertisements and loyalty programs) are used by retailers to increase their turnover and profit. In this section, the basic ideas of retail chains' pricing and price promotion as well as pricing strategies typically applied in a recession economy are introduced. 


\subsection{Retail pricing strategies}

Retail stores can compete in many aspects, but pricing strategy is the most important element of their marketing toolkit (Levy et al. 2004). A pricing strategy involves decisions on baseline prices and promotional activities, mainly price discounts. According to Hoch et al. (1994), there are two main types of strategies: everyday low price (EDLP) and promotion-oriented pricing (HiLo).

EDLP indicates continuously low prices, therefore promotion can play only a minor role. Price uncertainty in an EDLP store is very low, and consumers can anticipate that prices do not change materially between two shopping trips. In contrast, HiLo indicates higher baseline prices coupled with intensive (price) promotion activity. The price of a product sold at a temporary discount can be lower than the price of the same product in an EDLP store.

In reality, however, the pricing landscape is far more complex. Ellickson Misra (2008) defined the hybrid pricing strategy as the combination of EDLP and HiLo. Their dataset indicates a wide variety of hybrid pricing, some retailers being closer to EDLP, others closer to HiLo. According to them, pricing strategies should be interpreted at the store- and not at the chain-level. Bolton - Shankar (2003) identified five different store-level pricing strategies (exclusive pricing, premium pricing, HiLo pricing, low pricing, and aggressive pricing) in their empirical analysis carried out in five US cities. Surprisingly, EDLP was not on their list. However, the most general type, low pricing (found in $43 \%$ of stores), is defined as a combination of low prices and low promotional activity, with medium price variation. They observed that HiLo pricing is adopted by only $9 \%$ of stores. On the other hand, exclusive and premium pricing - a combination of high prices and low or medium promotional activity - are more widespread than HiLo.

The success of a pricing strategy can be determined by many factors. The experiments conducted by Hoch et al. (1994) provided the conclusion that HiLo is significantly more profitable than EDLP. Conversely, EDLP chains regularly outperformed HiLo chains with regard to profitability. Lal - Rao (1997) gave an explanation for this phenomenon using a game theoretical approach. Their main idea was that consumers' opportunity cost for travel time differs. Some consumers are willing to visit both EDLP and HiLo stores to make a bargain, while others always visit only one store. The total basket of goods is cheaper in an EDLP store, therefore a higher ratio of the latter consumer group will prefer EDLP stores. This can cause a higher profit rate. The above-mentioned contradiction in research findings can be clarified assuming that consumers have different preferences. Bell - Lattin (1998) pointed out that "large basket" shoppers prefer ELDP stores, while others prefer HiLo. 
Other studies (Shankar - Bolton 2004; Ellickson - Misra 2008; Volpe 2011) indicate that the demographic characteristics of the trade area (e.g. monthly income, family size) as well as the pricing strategy followed by rivals have the most important effect on the pricing strategy of a retail shop. In addition, the studies claim that pricing strategies are strategic complements (i.e. if the neighbouring store plays EDLP, then it will be worth playing it for the store in question as well) rather than substitutes.

The empirical results presented above suggest that there is no single successful way to go. Whether a pricing strategy will succeed or not depends largely on the market situation and the macroeconomic environment.

\subsection{Pricing strategies in recession}

When internal demand falls, the importance of pricing will increase due to the diminishing purchasing power of households. Shama (1978) examined changes in the marketing mix during stagflation (i.e. recession plus inflation). His results show that pricing changed considerably.

Chou - Chen (2004) analysed the success of pricing strategies during recession in Taiwan. Their analysis partially supported the hypothesis that for retail companies with abundant resources operating in a market where consumers are price sensitive, a predatory pricing strategy leads to higher market performance. Predatory pricing means that firms try to use the lowest prices to gain market share. Therefore, they also join price wars. Market share and turnover increased immediately due to this strategy; however, long-term consumer satisfaction and net profit suffered, indicating that the sustainability of this strategy is questionable.

Rao et al. (2000) claimed that price reduction can be the easiest and fastest reaction to recession, but the profitability of the company can decrease dramatically. According to a McKinsey study, a 1\% price increase can raise the profit of the firm by $11 \%$ (Cram 2004). Piercy et al. (2010) called attention to the long-run effects of these decisions. Even in a recession environment, pricing decisions have a long-term influence on the success of a company.

Jankuné Kürthy et al. (2012) found that Hungarian retailers reacted in several ways. They reduced the variety of goods sold, introduced new private label products, and tried to reduce the costs of store operation (for example, by opening smaller stores than before). 


\section{THE HUNGARIAN FOOD RETAIL SECTOR ${ }^{1}$}

Following the economic and social transition in the early 1990s, previously stateowned retail stores were privatised in Hungary. After the privatisation period, two types of food retail chains emerged: multinational and domestic retail chains.

In the early 1990s, several international retail chains entered the market, e.g. Tengelmann (Plus, Kaiser's), Louis Delhaize (Profi, Match, Cora), ASPIAG (Spar, Interspar), and acquired stores through privatisation. Similarly to other transition economies, the market share of multinational chains rose rapidly in Hungary (Minten - Reardon 2008). The first entrants were soon followed by other multinational chains (e.g. Tesco, Auchan, and Rewe/Penny Market). After Hungary joined the European Union in 2004, Lidl, a German hard discount chain, began to expand in Hungary. Finally, Aldi entered the Hungarian food retail market in 2008.

These chains have several types of stores: hypermarkets, supermarkets, and discount stores. The main difference between them is assortment and size of retail area. Discount stores mainly sell private label products, while hypermarkets offer full lines of fast-moving consumer goods (FMCG).

Domestic food retail chains such as CBA, Coop, and Reál have embraced independent retailers in the form of buying groups and franchise systems. In consequence, these chains have a much more heterogeneous structure compared to multinational chains. The store portfolio of domestic chains mainly covers traditional shops, but also modern supermarkets (like CBA Príma stores).

The increasing number of entrants and the decreasing internal demand led to intense competition. The market started to consolidate in 2008, through acquisitions and market exits; thus, concentration increased. Spar acquired the entire Plus network and Plus stores were converted into Spar supermarkets. The Louis Delhaize Group (the owner of Cora hypermarkets, Match supermarkets, and Profi discount stores) also left the Hungarian market in 2011-2013. Cora hypermarkets were taken over by Auchan at the end of 2011; however, Match and Profi were operated by Louis Delhaize Group until the end of 2012. Therefore, at the time of the empirical research, Match and Profi were active in the Hungarian retail market. 


\section{METHODOLOGY AND DATA COLLETION}

The research methodology included in-store observations, the analysis of price promotion leaflets, and interviews. The in-store observations and leaflet analysis were carried out in two phases (at the end of 2011 and at the beginning of 2012).

\subsection{Baseline prices}

Baseline prices were collected using in-store observations. Stratified probability sampling was used to draw a 44-store sample out of the stores of 11 food retail chains (Aldi, CBA Príma, G’Roby, Interspar, Lidl, Match, Penny Market, Profi, Spar, Tesco, and Tesco Expressz) in Budapest. Table 1 shows the summary statistics of the survey.

In every store, baseline prices of 15 well-specified products were collected. ${ }^{2}$ Following Minten et al. (2010), high-frequency purchased goods were chosen.

\section{Table 1}

Retail chains in Budapest (on 20 December 2011) and the distribution of the sample

\begin{tabular}{lccccr}
\hline Retail chain & $\begin{array}{c}\text { Number of } \\
\text { stores }\end{array}$ & $\begin{array}{c}\text { Proportion, } \\
\%\end{array}$ & $\begin{array}{c}\text { Stores in the } \\
\text { sample }\end{array}$ & $\begin{array}{c}\text { Sample } \\
\text { proportion, \% }\end{array}$ & $\begin{array}{c}\text { Difference, } \\
\text { pp }\end{array}$ \\
\hline Hypermarkets & 22 & 7.4 & 3 & 6.8 & -0.6 \\
Interspar & 6 & 2.0 & 1 & 2.3 & 0.2 \\
Tesco & 13 & 4.4 & 2 & 4.5 & 0.2 \\
Auchan & 3 & 1.0 & 0 & 0 & -1.0 \\
Supermarkets & 207 & 69.9 & 32 & 72.7 & 2.8 \\
Spar & 97 & 32.7 & 15 & 34.1 & 1.3 \\
G'Roby & 5 & 1.7 & 1 & 2.3 & 0.6 \\
Match & 41 & 13.9 & 6 & 13.6 & -0.2 \\
CBA Príma & 37 & 12.5 & 6 & 13.6 & 1.1 \\
Tesco Expressz & 27 & 9.1 & 4 & 9.1 & 0.0 \\
Discount stores & 67 & 22.6 & 9 & 20.5 & -2.2 \\
Lidl & 22 & 7.4 & 3 & 6.8 & -0.6 \\
Aldi & 15 & 5.1 & 2 & 4.5 & -0.5 \\
Profi & 14 & 4.7 & 2 & 4.5 & -0.2 \\
Penny Market & 16 & 5.4 & 2 & 4.5 & -0.9 \\
Total & 296 & 100.0 & 44 & 100.0 & 0.0 \\
\hline
\end{tabular}

Source: Homepages of the retail chains and author's own calculations.

2 If a product was part of a price promotion at the time of the data collection, baseline (i.e. nonpromotional) price was collected, too (these often appeared on the shelves). 
Branded products sold in every retail chain were selected. Should a product not be sold by a retailer, the prices of similar products were used to estimate the price of the unavailable product. Half of the products represent manufacturer brands, while the other half is made up of private labels. Summary statistics for the observed products and prices are presented in Table 2.

Similarly to the research design of Cataluña et al. (2005), stores were visited twice: first between 27 and 30 December 2011, and second between 22 and 24 January 2012. There was an increase in VAT in Hungary from 1 January 2012. The date of visiting was chosen so that the introduction of the VAT increase (a cost shock) falls between the two visits. If the distribution of the prices is similar before and after the tax shock, the results can be deemed more reliable.

Table 2

Summary statistics from the in-store observations of prices

\begin{tabular}{|c|c|c|c|c|c|c|}
\hline \multirow[t]{2}{*}{ Product } & \multicolumn{2}{|c|}{$\begin{array}{c}\text { Number of observed } \\
\text { prices }\end{array}$} & \multicolumn{2}{|c|}{$\begin{array}{c}\text { Number of estimated } \\
\text { prices }\end{array}$} & \multicolumn{2}{|c|}{$\begin{array}{l}\text { Average observed } \\
\text { price (HUF) }\end{array}$} \\
\hline & $\begin{array}{c}\text { December } \\
2011\end{array}$ & $\begin{array}{c}\text { January } \\
2012\end{array}$ & $\begin{array}{l}\text { December } \\
2011\end{array}$ & $\begin{array}{c}\text { January } \\
2012\end{array}$ & $\begin{array}{l}\text { December } \\
2011\end{array}$ & $\begin{array}{c}\text { January } \\
2012\end{array}$ \\
\hline \multicolumn{7}{|c|}{ manufacturer branded products } \\
\hline Soproni lager beer $(0.51)$ & 44 & 44 & 0 & 0 & 208 & 212 \\
\hline Coca-cola $(21)$ & 44 & 44 & 0 & 0 & 335 & 346 \\
\hline $\begin{array}{l}\text { Füstli Wiener sausage } \\
(350 \mathrm{~g})\end{array}$ & 38 & 38 & 6 & 6 & 649 & 701 \\
\hline $\begin{array}{l}\text { Vénusz sunflower oil } \\
\text { (1 l l) }\end{array}$ & 41 & 41 & 3 & 3 & 470 & 475 \\
\hline $\begin{array}{l}\text { Vénusz margarine } \\
(450 \mathrm{~g})\end{array}$ & 36 & 32 & 8 & 12 & 435 & 446 \\
\hline Kinder Surprise (1 piece) & 44 & 44 & 0 & 0 & 208 & 212 \\
\hline $\begin{array}{l}\text { Pöttyös Guru milk } \\
\text { dessert (38 g) }\end{array}$ & 43 & 43 & 1 & 1 & 104 & 106 \\
\hline $\begin{array}{l}\text { Douwe Egberts Omnia } \\
\text { coffee }(250 \mathrm{~g})\end{array}$ & 42 & 42 & 2 & 2 & 891 & 963 \\
\hline \multicolumn{7}{|c|}{ private label products } \\
\hline $100 \%$ orange juice $(11)$ & 44 & 44 & 0 & 0 & 289 & 295 \\
\hline Bread $(1 \mathrm{~kg})$ & 44 & 44 & 0 & 0 & 238 & 241 \\
\hline Half fat UHT milk (1 1) & 44 & 44 & 0 & 0 & 195 & 193 \\
\hline 'Parisian' cutlet (1 kg) & 44 & 44 & 0 & 0 & 502 & 495 \\
\hline Sugar $(1 \mathrm{~kg})$ & 44 & 44 & 0 & 0 & 300 & 307 \\
\hline Wheat flour (1 kg) & 44 & 44 & 0 & 0 & 123 & 123 \\
\hline Canned corn $(340 \mathrm{~g})$ & 44 & 44 & 0 & 0 & 168 & 166 \\
\hline
\end{tabular}

Note: The estimated prices are based on prices of similar, branded products.

Source: Author's own research design and observations. 
Altogether, 1,320 prices of products were collected. To make the prices comparable, scaled prices were used. According to Fertő - Bakucs (2009), scaled prices are calculated by dividing the prices of a product by their mode. The analysis was performed with these transformed prices.

Drawing conclusions from a relatively low number of products is not a unique phenomenon in the relevant literature. Györe et al. (2009) graded store formats analysing the prices of only 10 products. Monteiro et al. (2012) compared the price levels of large supermarket chains and small independent supermarkets using the prices of 22 products.

To compare the structure of the baseline prices of the stores, average price levels and price variations were compared using analysis of variance (ANOVA). Identical variation of prices in several stores is a prerequisite for ANOVA according to Füstös et al. (2004). The Levene statistic was applied to control for the homogeneity of group variances. Cataluña et al. (2005) and Bolton - Shankar (2003) used the same statistical tool to compare the price levels of several shops.

First, the validity of the "law of one price" was examined. This law states that homogeneous products should be sold at the same price in different stores that are relatively close to each other. The reason behind this is as follows: if a store charges higher prices, consumers will go to its rival and buy the product there. However, empirical evidence almost never verifies the "law of one price" (Zhao 2006). Based on the in-store observations, there are significant differences in baseline price levels among Hungarian retail stores.

Table 3

Mean and variation of scaled prices at retail chains

\begin{tabular}{lcc}
\hline Retail chain/group & Mean of scaled prices & $\begin{array}{c}\text { Variation of scaled } \\
\text { prices }\end{array}$ \\
\hline Aldi & 1.006 & 0.156 \\
CBA Príma 1 & 1.213 & 0.491 \\
CBA Príma 2 & 1.111 & 0.168 \\
G'Roby & 1.173 & 0.452 \\
Interspar & 0.973 & 0.043 \\
Lidl & 0.989 & 0.154 \\
Match & 1.108 & 0.136 \\
Penny Market & 0.988 & 0.108 \\
Profi & 1.059 & 0.147 \\
Spar & 0.974 & 0.039 \\
Tesco & 0.939 & 0.094 \\
Tesco Expressz & 1.059 & 0.109 \\
\hline
\end{tabular}

Source: Author's own calculations. 
Second, the variation and mean values of baseline prices were compared for stores belonging to the same chain. A separate analysis was carried out for prices collected in December 2011 and in January 2012. Then, means and variations of (scaled) prices were compared across the stores to identify whether there is a difference between the December 2011 and the January 2012 data. Due to the relatively small sample size, high critical values were used. The null hypothesis was rejected if the significance level was less than $10 \%$.

The results of these analyses show that almost every retail chain adopts similar prices in its stores. The only exception is CBA Príma. This is a franchise brand, therefore retailers determine prices individually. Two different types of CBA Príma stores were identified. Table 3 shows the detailed results. The price manager of Tesco also suggested in an interview that multinational retail chains determine the prices at their headquarters, therefore the variation of prices among stores is very low.

\subsection{Price promotion activity}

The pricing strategy is also influenced by the price promotion activity of a retailer. Price promotions are communicated in retailers' promotion leaflets. The importance of price promotions is even greater in a time of recession. According to GfK Hungary, $61 \%$ of the population who receive price promotion leaflets regularly study promotional prices (Élelmiszer 2011).

Price promotion leaflets published between December 2011 and January 2012 were collected during a 5-week period. This investigation was carried out at chain-level as price promotion leaflets are published by the headquarters of the chains and are valid in every store. All the food and beverage products published in price promotion leaflets were analysed, not only the 15 chosen for the baseline price analysis.

The price promotion activity of a retail chain can be analysed using several factors. Following Bolton - Shankar (2003), the depth, the duration, and the frequency of price promotions were measured. The analysis was based on three transformed measures. The depth of promotion was assessed by the difference (in percent) between baseline and promotional prices. This difference was calculated for every food and beverage product appearing in any of the price promotion leaflets in the examined 5-week period. The sample average of these differences (in percent) was used as the indicator of the depth of the promotion (hereinafter referred to as "average discount"). 
Instead of the duration of price promotions, I used the average number of promoted products. This indicator was calculated using the following formula for the 11 examined retail chains:

\section{length of promotion (dav) $\times$ products sold at a discount (number) length of the observed period (day)}

where length of promotion means for how long the price promotion was valid for the products sold at a discount; length of the observed period is the total number of days of the $c a$. 5-week period (it varied across chains because the validity of the price promotion leaflets differed from chain to chain). All the price promotion leaflets published in the $c a$. 5-week period were used to calculate this indicator. This transformation was necessary because some discount chains (such as Aldi or Lidl) run price promotions valid for different time periods at the same time (e.g. discounts only on a Sunday / a weekend, or discounts valid for a whole week). The higher the value of this indicator, the more active the promotional activity of the given chain.

Finally, the frequency of price promotions was quantified as the quotient of advertised promotion periods (number in the observed time period) and the length of the observed period (in days). This quantifies how often the given retail chain advertised a new price promotion period (e.g. the value for Aldi, 0.43 , means that on $43 \%$ of days, i.e. a new price promotion period began on almost every second day).

Table 4

Measurements of price promotion activity at retail chains

\begin{tabular}{lccc}
\hline Retail chain & $\begin{array}{c}\text { Average discount, } \\
\%\end{array}$ & $\begin{array}{c}\text { Average number of } \\
\text { promoted products }\end{array}$ & $\begin{array}{c}\text { Frequency of price } \\
\text { promotions }\end{array}$ \\
\hline Aldi & 22 & 32 & 0.43 \\
CBA Príma & 25 & 173 & 0.24 \\
G'Roby & 19 & 21 & 0.17 \\
Interspar & 24 & 118 & 0.41 \\
Lidl & 26 & 58 & 0.48 \\
Match & 23 & 66 & 0.08 \\
Penny Market & 21 & 108 & 0.38 \\
Profi & 26 & 91 & 0.14 \\
Spar & 33 & 109 & 0.35 \\
Tesco & 24 & 219 & 0.18 \\
Tesco Expressz & 24 & 30 & 0.18 \\
\hline
\end{tabular}

Source: Author's own calculations. 
The average discount and the average number of promoted products as well as the frequency of price promotions were calculated for every retail chain. Table 4 displays the results of the survey.

To verify the results of the in-store observations and leaflet analysis, interviews were conducted. The interviews took place after the analyses of the baseline prices and price promotions.

The aims of the interviews were to expose the trends in the Hungarian food retail industry as well as to obtain detailed information about the pricing strategies of the given firm and its rivals. The interviews also enabled me to check the validity of the empirical findings. Furthermore, they highlighted the retailers' point of view on the role of pricing during the economic crisis. The information gathered from the interviews is used in Section 5 to illustrate the developments in the Hungarian food retail industry in recent years.

\section{RESULTS AND DISCUSSION}

The aim of this paper is to identify the pricing strategies of the Hungarian food retail sector and evaluate them with regard to market and financial performance measures during a time of economic crisis. Based on the baseline prices and price promotion activities (Tables 3 and 4), I used hierarchical cluster analysis to identify the currently applied pricing strategies. In this section, the results of the cluster analysis are presented.

To make the variables suitable for cluster analysis, I carried out data transformations as suggested by Füstös et al. (2004). As baseline prices and promotional activities are equally important components of a pricing strategy, pairs of variables regarding baseline prices and promotional activities were used. Therefore, a new variable (intensity of promotion) was created as the average of the frequency and number of promoted products. Moreover, all the variables (except the mean of scaled prices) were centred around their sample mean.

\subsection{Identified pricing strategies}

Taking into account the distance between the chains that belong to the same cluster, three clusters were created. Table 5 contains the values of the four relevant variables (mean of scaled prices, variation of prices, average discount, and intensity of promotion) for every group as well as the retail chains that belong to the given cluster. ANOVA was performed to test the differences of the mean values of the variables. The critical values of the tests are very low, indicating significant 
differences among the groups. Only the average discount is the same among the clusters. The three clusters represent different pricing strategies, which I labelled as aggressive pricing, premium pricing, and HiLo pricing.

The members of the first cluster play the aggressive pricing strategy. These chains operate with low prices, medium high price variation, and very intense price promotion activity. This strategy is a hybrid, where low prices are combined with frequent price promotions. In addition, this is the most general pricing strategy, as $61 \%$ of the stores pursue it. It is interesting that Chou - Chen (2004) found a similar pricing strategy in Taiwan in a recession environment (they called it predatory pricing).

However, this is a very mixed group containing super- and hypermarkets as well as discount stores. The presence of Spar, a rather high category supermarket in this cluster is very surprising. Before the economic crisis that started in 2008, Spar positioned itself as a premium retail brand. However, with close to 400 affiliates, Spar is the fourth biggest food retail chain in Hungary. After 2008, customers became more and more price sensitive due to the reduction in their income. Spar had to respond to the fast market penetration of discount stores. The results of the cluster analysis clearly show that Spar has begun to use the same pricing strategy as the discount stores.

Premium pricing (cluster 2) can be described as using higher prices than the aggressive pricing strategy, but less intense price promotion activity. This is again a hybrid strategy, but it is more widespread in Hungary compared to other empirical findings. Bolton - Shankar (2003) identified a similar pricing strategy (called exclusive pricing), but only $2.3 \%$ of the stores were playing it. In Hungary, more

Table 5

Identified pricing strategies and the average of the relevant centred variables

\begin{tabular}{lccc}
\hline Variable & Cluster No. 1 & Cluster No. 2 & Cluster No. 3 \\
\hline Name & $\begin{array}{c}\text { Aggressive pricing } \\
\text { Mesco, Interspar, } \\
\text { Spar, Penny Market, } \\
\text { Lidl, Aldi, CBA } \\
\text { Príma 2 }\end{array}$ & $\begin{array}{c}\text { Premium pricing } \\
\text { Tesco Expressz, } \\
\text { Profi, Match }\end{array}$ & $\begin{array}{c}\text { HiLo pricing } \\
\text { G'Roby, CBA } \\
\text { Príma 1 }\end{array}$ \\
Mean of scaled prices & 0.997 & & \\
Variation of prices & 0.568 & 1.075 & 1.193 \\
Average discount & 1.030 & 0.382 & 1.801 \\
Intensity of promotion & 1.265 & 1.002 & 0.906 \\
\hline
\end{tabular}

Note: CBA Príma is a franchise brand, therefore the pricing strategy varies significantly across stores (there are two different types of stores). It is not true for the rest of the chains.

Source: Author's own calculations. 
than $27 \%$ of stores belong to this category, an extremely high proportion. Profi and Match are good examples of the premium pricing strategy.

Profi and Match are retail chains with a long history in Hungary; they acquired most of their stores during the privatisation of the retail sector between 1990 and 1993. Their stores can be found in the most frequented locations of Budapest and in Hungary's biggest towns. On the other hand, Tesco Expressz is the most recent store format (convenience shop) in Hungary, located in frequented localities in cities. The research results suggest that these chains did not adopt the pricing strategy of the previous group.

Finally, HiLo pricing (cluster 3) denotes high baseline prices with very high price variation. This means that even though prices are high, one can sometimes make a bargain. In fact, this may well happen, since the high prices are supported by medium high price promotion activity. However, this strategy is not widespread at all, with only $11 \%$ of stores playing it (e.g. some CBA Príma stores).

\subsection{The relationship between pricing strategy and market performance}

Several measurements are able to show the market and financial performance of a retail chain. In this paper, the change in market share, turnover per store, and net operating profit are studied, respectively. The additional advantage of using several variables is that it makes it possible to take into account that different chains may have different targets (e.g. a profit target for a product category, a profit target for the whole shop or a market share target).

Figure 1 represents changes in market share from 2008 to 2012. Retail chains belonging to the first group gained market share from other stores. For example, Lidl, which used the aggressive pricing strategy from the beginning, increased its market share by more than $50 \%$. Premium pricing shows the poorest performance. Profi's market share decreased by $30 \%$; Match's market share decreased by 45\%. Aldi, which entered the Hungarian market in 2008, passed Profi in 2009 and reached the combined market share of Profi and Match by 2011.

The market share of CBA, which operates as a franchise chain with a heterogeneous store network, has stayed approximately the same over the past few years. According to Attila Fodor, the communications leader of the CBA franchise firm, the market share of CBA Príma had increased slightly.

Market shares might change for two reasons. First, expansions can increase the market share, but this growth strategy varies sharply across retail chains. Second, pricing strategy might boost the market share by increasing the turnover of the extant stores. Therefore, turnover per store is also an interesting indicator. Table 6 shows a partly different picture compared to Figure 1 . The most glaring differ- 


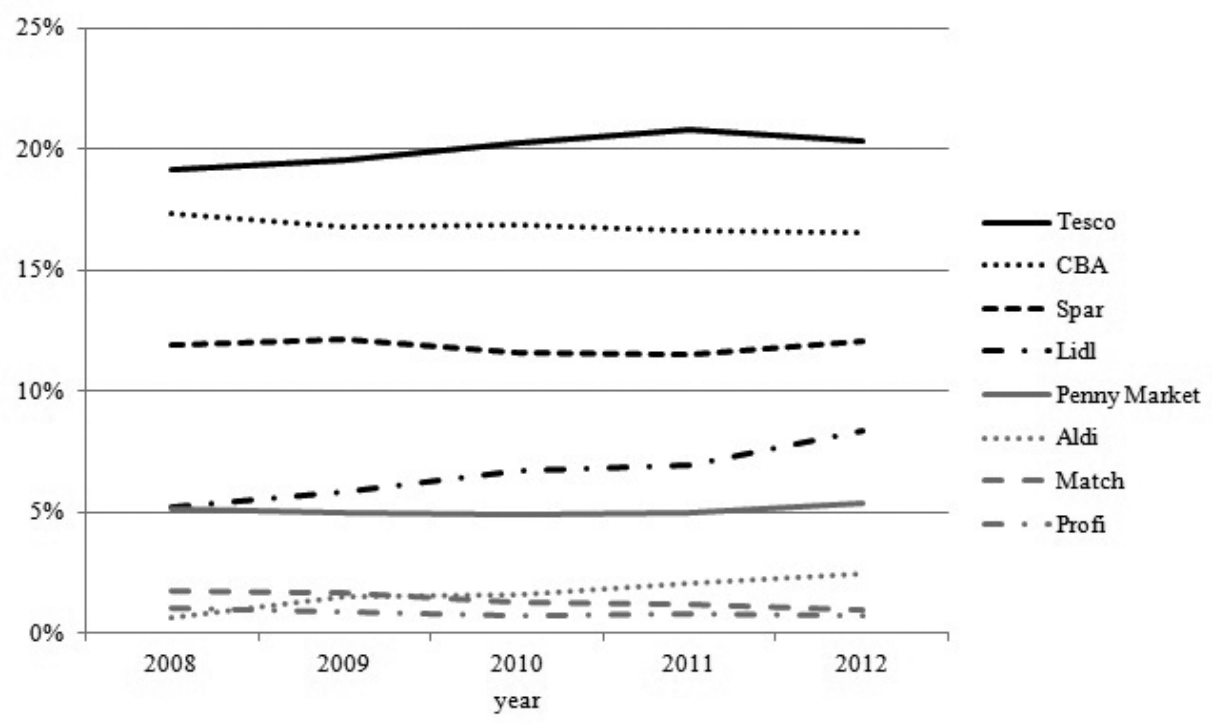

Figure 1. Market shares in the Hungarian food retail sector

Note: The market share of G'Roby is very small compared to the other chains.

Source: ACNielsen.

ence is in Tesco's performance. This measure indicates a 20\% loss in the turnover per store from 2008 to 2012 . The reason behind this may at least partially be the fact that the proportion of hypermarkets among stores decreased from $60 \%$ to $55 \%$ and supermarkets generally underperform hypermarkets in terms of turnover. Another explanation may be that Tesco increased the number of stores by $50 \%$ in this time period, and this inevitably causes some reduction in this variable. Except for Tesco, turnover per store supports the conclusions based on the change of market share: aggressive pricing and HiLo pricing were successful, while premium pricing performed poorly.

Finally, it is worth discussing the size of net operating profits. Turnover and market share can be increased by price reductions, but these steps will considerably damage profitability. Table 7 gives an overview of net operating profits from 2008 to 2012.

Profi and Match, the dominant members of the second cluster, generated negative operating profits every year. Moreover, the loss rose over the years. All three performance measures indicate that premium pricing was not successful in the time period under review. 
Table 6

Turnover per store $(2008=100.0)$

\begin{tabular}{|c|c|c|c|c|c|}
\hline Retail chain & 2008 & 2009 & 2010 & 2011 & 2012 \\
\hline Tesco & 100.0 & 89.2 & 79.9 & 81.8 & 80.7 \\
\hline CBA & 100.0 & 99.9 & 100.7 & 102.4 & 100.0 \\
\hline G'Roby & 100.0 & 109.8 & 105.4 & 129.0 & 114.4 \\
\hline Spar & 100.0 & 104.3 & 99.9 & 104.7 & 112.6 \\
\hline Penny Market & 100.0 & 95.1 & 90.5 & 93.4 & 102.9 \\
\hline Lidl & 100.0 & 99.9 & 104.4 & 101.1 & 118.9 \\
\hline Match & 100.0 & 101.9 & 78.2 & 77.8 & 80.8 \\
\hline Profi & 100.0 & 87.6 & 75.8 & 84.8 & 77.9 \\
\hline Aldi & 100.0 & 189.5 & 161.3 & 198.0 & 221.3 \\
\hline
\end{tabular}

Source: ACNielsen, Profit and loss statements (G'Roby).

Table 7

Net operating profit (million HUF)

\begin{tabular}{lrrrrr}
\hline Retail chain & 2008 & 2009 & 2010 & \multicolumn{1}{c}{2011} & \multicolumn{1}{c}{2012} \\
\hline Tesco & 11,991 & 10,906 & 4,899 & 8,163 & 841 \\
G'Roby & 22 & 58 & 10 & 45 & 63 \\
Spar & 6,829 & $-8,750$ & $-14,092$ & $-19,840$ & $-17,095$ \\
Penny Market & 2,367 & 705 & 404 & 671 & 1,245 \\
Lidl & 6,614 & 5,898 & 6,398 & 3,211 & $-4,009$ \\
Match & -606 & $-2,394$ & $-2,798$ & $-3,140$ & $-8,129$ \\
Profi & -207 & -927 & -966 & $-1,341$ & $-3,723$ \\
Aldi & $-9,278$ & $-10,099$ & $-7,561$ & $-7,066$ & $-5,315$ \\
\hline
\end{tabular}

Note: Net operating profit is not available for CBA Príma, which is a franchise brand with many retailers. Source: Profit and loss statements of the companies.

Aggressive pricing (i.e. the first cluster) shows ambiguous results. Some chains (Lidl, Penny Market, Tesco) achieved positive operating profits almost every year. On the other hand, Spar and Aldi realised huge losses. Spar was a premium brand, but it has repositioned itself during the crisis, which required heavy investments in marketing to change consumers' perceptions of the chain. Aldi may need more time to reach an efficient operating size. The research findings support this explanation, since operating losses have steadily decreased over the years.

It is difficult to evaluate the performance of HiLo pricing. This is a premium segment for chains with only a few stores, usually in the middle of a city or in an affluent neighbourhood of Budapest. Nevertheless, the available data and the in- 
terviews suggest that these stores could defend or even increase both their market position and financial performance.

Table 8 summarises the results discussed above. Surprisingly, the most successful strategy (aggressive pricing) is very similar to the predatory pricing strategy found by Chou - Chen (2004), according to whom net profit decreased in Taiwan. Even more interesting is that the consequences of these strategies are quite similar in Taiwan and in Hungary. The aggregate profits of the members of the first cluster also shrank in Hungary from one year to the next (see Table 7).

It also appears that pricing strategies are strategic complements in Hungary. The market and financial performance of the chains playing the aggressive pricing strategy were at least partially favourable, while chains adopting premium pricing achieved extremely bad results. Róbert Ruga, the marketing director of Profi explicitly mentioned in an interview that they have avoided employing the same pricing strategy as their rivals (Hönyi 2011). This behaviour has led to poor market performance. Many other studies (e.g. Ellickson - Misra 2008; Volpe 2011) came to the same conclusion with regard to other countries.

Table 8

Comparison of the three identified pricing strategies

\begin{tabular}{|c|c|c|c|}
\hline Variable & Aggressive pricing & Premium pricing & HiLo pricing \\
\hline Store types & $\begin{array}{l}\text { discount stores, } \\
\text { hyper- and } \\
\text { supermarkets }\end{array}$ & $\begin{array}{l}\text { discount stores and } \\
\text { supermarkets }\end{array}$ & supermarkets \\
\hline $\begin{array}{l}\text { Average baseline } \\
\text { prices }\end{array}$ & low & medium & high \\
\hline $\begin{array}{l}\text { Variation of baseline } \\
\text { prices }\end{array}$ & medium & low & very high \\
\hline Average discount & \multicolumn{3}{|c|}{ does not vary across strategies } \\
\hline $\begin{array}{l}\text { Intensity } \\
\text { of promotion }\end{array}$ & very high & low & medium \\
\hline Market share & $\begin{array}{l}\text { increasing or weakly } \\
\text { decreasing }\end{array}$ & $\begin{array}{l}\text { significantly } \\
\text { decreasing }\end{array}$ & unchanged \\
\hline Turnover per store & $\begin{array}{l}\text { increasing or weakly } \\
\text { decreasing }\end{array}$ & $\begin{array}{c}\text { significantly } \\
\text { decreasing }\end{array}$ & $\begin{array}{c}\text { increasing or } \\
\text { unchanged }\end{array}$ \\
\hline $\begin{array}{l}\text { Net operating profit } \\
\text { Importance of the } \\
\text { group }\end{array}$ & $\begin{array}{l}\text { positive in general } \\
\text { very important }\end{array}$ & $\begin{array}{c}\text { negative in general } \\
\text { diminishing, but still } \\
\text { important }\end{array}$ & $\begin{array}{l}\text { positive in genera } \\
\text { not important }\end{array}$ \\
\hline
\end{tabular}

Source: Author's own results. 


\section{CONCLUSION}

The goal of this paper was to identify and evaluate the pricing strategies of 11 Hungarian food retail chains in a time of recession characterised by decreasing demand. The findings clearly indicate that there were three distinct types of pricing strategies (aggressive pricing, premium pricing, and HiLo pricing). The most widespread of the three, aggressive pricing, is a hybrid strategy with low baseline prices (like EDLP) but medium price variation and very intense price promotion activity (like HiLo). Premium pricing is a hybrid strategy as well. These chains operate using higher baseline prices (like HiLo), but not supported by strong price promotion. On the contrary, the price promotion activity of these chains is very weak (a common feature with EDLP). HiLo pricing is less widespread in Hungary. Only few shops adopt this strategy that provides high prices and medium price promotion. The empirical research could not identify retailers using a pure EDLP strategy.

Based on the empirical results and the interviews, the link between pricing strategy and market performance was identified. Several market performance measures (market share, turnover per store, and net operating profits) indicate that the aggressive pricing strategy (i.e. low prices, but intensive price promotion) was the most successful. Conversely, the premium pricing strategy (i.e. medium prices and low price promotion) was a complete failure. The chains applying it lost market share from year to year, and, on top of that, their net operating profits were negative in every year from 2008 to 2012. Chains adopting the HiLo pricing maintained their market and financial positions, but this segment comprises only a small part of the total market.

Nevertheless, the most successful strategy revealed disadvantages as well. The profitability of the firms decreased, which indicates that changes are needed in the long run. Bachl et al. (2010) reviewed the big price war in Germany in 2009. Following the price war, market shares remained unchanged, but profits decreased significantly. This indicates that the price war was not an effective tool in gaining market share. They established that it is time for a paradigm change by reverting back to EDLP or HiLo. In my opinion - based on my findings - retail stores should reduce price promotions, but also operate with lower prices in the future. This means that pricing strategies would be more similar to EDLP.

The main limitation of the research is the relatively small set of price data used to determine the baseline prices of the retail units. It would be interesting to repeat the research using a larger dataset. It may also be a fruitful research area to analyse the changes in pricing strategies after the recession period. Future research may provide an answer to whether pricing strategies will move in the direction of EDLP, HiLo or other hybrid strategies. 


\section{REFERENCES}

Bachl, T. - Adlwarth, W. - Claassen, A. - Dreisbach, D. (2010): Preisoptimierung im deutschen Lebensmitteleinzelhandel (Price Optimization in the German Food Retail Sector). Nürnberg: GfK Panel Service Deutschland and SAP Deutschland.

Bell, D. R. - Lattin, J. M. (1998): Shopping Behavior and Consumer Preference for Store Price Format: Why "Large Basket" Shoppers Prefer EDLP. Marketing Science, 17(1): 66-88.

Bolton, R. N. - Shankar, V. (2003): An Empirically Derived Taxonomy of Retailer Pricing and Promotion Strategies. Journal of Retailing, 79(4): 213-224.

Cataluña, F. J. R. - Franco, M. J. S. - Ramos, A. F. V. (2005): Are Hypermarket Prices Different from Discount Store Prices? Journal of Product \& Brand Management, 14(5): 330-337.

Chou, T. J. - Chen, F. T. (2004): Retail Pricing Strategies in Recession Economies: The Case of Taiwan. Journal of International Marketing, 12(1): 82-102.

Cram, T. (2004): Boost Brand and Profit with the Right Price. Financial Times, 35525: 9.

Ellickson, P. B. - Misra, S. (2008): Supermarket Pricing Strategies. Marketing Science, 27(5): 811-828.

Élelmiszer (2011): Minden negyedik ember vásárol akciós újság alapján. Hasznosak az akciós újságok (Every Fourth Person Buys Using Price Promotion Leaflets. Leaflets are Useful). Élelmiszer, XIX(3): 30.

Euromonitor (2010): Retailing in Hungary. London: Euromonitor International.

Fertő, I. - Bakucs, L. Z. (2009): Árleszállítások és a kiskereskedelmi árak változása a tejtermékek piacán (Sales and Retail Price Patterns on the Market for Milk Products). Közgazdasági Szemle, LVI(July-August): 634-647.

Füstös, L. - Kovács, E. - Meszéna, Gy. - Simonné Mosolygó, N. (2004): Alakfelismerés (Sokváltozós statisztikai módszerek) (Form Recognition - Statistical Analyses with Many Variables). Budapest: Dico and Új Mandátum Publishers.

GfK Hungary (2011): Hungarians Go Shopping Less Frequently. Importance of Promotions and Special Offers Increases. Budapest: GfK Hungary Press Release.

Györe, D. - Popp, J. - Stauder, M. - Tunyoginé Nechay, V. (2009): Az élelmiszer-kiskereskedelem beszerzési és árképzési politikája (Supply Management and Pricing Policy of the Food Retail Trade). Budapest: Research Institute of Agricultural Economics.

Hoch, S. J. - Drèze, X. - Purk, M. E. (1994): EDLP, HiLo, and Margin Arithmetic. Journal of Marketing, 58(4): 16-27.

Hőnyi, Gy. (2011): Tart a bolt átalakítási láz a Profinál (There is Still Shop Reconstruction Time at Profi). Napi Gazdaság. Available at (30/04/2012): http://www.napi.hu/magyar_vallalatok/ tart a boltatalakitasi laz a profinal.480906.html

Jankuné Kürthy, Gy. - Stauder, M. - Györe, D. (2012): Az élelmiszer-kereskedelem termelékenysége és jövedelmezösége (The Productivity and Profitability of the Food Sale Sector in Hungary). Budapest: Research Institute of Agricultural Economics.

Juhász, A. (ed.) (2010): A kereskedelmi márkás termékek gyártásának hatása az élelmiszerkiskereskedelemre és beszállitóira (Effects of the Production of Private Label Goods on the Food Retail Trade and Its Suppliers). Budapest: Research Institute of Agricultural Economics.

Lal, R. - Rao, R. (1997): Supermarket Competition: The Case of Every Day Low Pricing. Marketing Science, 16(1): 60-80.

Levy, M. - Grewal, D. - Kopalle, P. K. - Hess, J. D. (2004): Emerging Trends in Retail Pricing Practice: Implication for Research. Journal of Retailing, 80(3): xiii-xxi. 
Minten, B. - Reardon, T. (2008): Food Prices, Quality, and Quality's Pricing in Supermarkets versus Traditional Markets in Developing Countries. Review of Agricultural Economics, 30(3): 480-490.

Minten, B. - Reardon, T. - Sutradhar, R. (2010): Food Prices and Modern Retail: The Case of Delhi. World Development, 38(12): 1775-1787.

Monteiro, G. - Farina, E. - Nunes, R. (2012): Food-Retail Development and the Myth of Everyday Low Prices: The Case of Brazil. Development Policy Review, 30(1): 49-66.

Piercy, N. F. - Cravens, D. W. - Lane, N. (2010): Thinking Strategically about Pricing Decisions. Journal of Business Strategy, 31(5): 38-48.

Rao, A. R. - Bergen, M. E. - Davis, S. (2000): How to Fight a Price War. Harvard Business Review, March-April: 107-116.

Shama, A. (1978): Management \& Consumers in an Era of Stagflation. Journal of Marketing, 42(3): 43-52.

Shankar, V. - Bolton, R. N. (2004): An Empirical Analysis of Determinants of Retailer Pricing Strategy. Marketing Science, 23(1): 28-49.

Vásáry, V. (2012): Change and Uncertainty - Challenges for Agriculture, Food and Natural Resources. Acta Oeconomica, 62(1): 103-108.

Volpe, R. (2011): Evaluating the Performance of U.S. Supermarkets: Pricing Strategies, Competition from Hypermarkets, and Private Labels. Journal of Agricultural and Resource Economics, 36(3): 488-503.

Zhao, Y. (2006): Price Dispersion in the Grocery Market. Journal of Business, 79(6): 1175-1192. 